\title{
Análise crítica do papel das inovações financeiras na crise do subprime *
}

\author{
Guilherme Santos Mello **
}

\section{Resumo}

Este artigo tem por objetivo estudar a importância central assumida pelo mercado de derivativos na dinâmica do capitalismo contemporâneo, debruçando-se particularmente sobre o mercado de derivativos de crédito e sua contribuição para a formação e eclosão da crise financeira que abalou os EUA e o mundo em 2007/2008. Esta dimensão está marcada pela forma derivativo, que altera as relações de propriedade, introduz novos agentes e motivações, aumenta a integração financeira entre os agentes e transforma a lógica de precificação dos principais mercados financeiros. Sendo assim, descreve-se a transformação pela qual passou o mercado de crédito imobiliário norte-americano, argumentando-se que tais mudanças ganharam vigor renovado e apenas se completaram com a ascensão e crescimento dos derivativos de crédito (CDS) e dos CDOs sintéticos, que foram fundamentais para a manutenção das taxas baixas de juros sobre as hipotecas, contribuindo assim diretamente para a bolha no mercado imobiliário que culminou na crise econômica.

Palavras-chave: Derivativos; Crise; Subprime; Marx; Quarta dimensão; Mercado imobiliário; Hipotecas.

\section{Abstract \\ The subprime crisis and the fourth dimension of capitalism - an Marxist approach}

This paper aims to study the central importance assumed by the derivatives market in the dynamics of contemporary capitalism, focusing in particular on the credit derivatives market and its contribution to the formation and the outbreak of the financial crisis that impacted the U.S. and the world economy in 2007/2008. This dimension is marked by the derivative form, that changes the property relations, introduces new agents and motivations, increases financial integration between the agents and transforms the pricing logic of the major financial markets. Therefore, the paper describes the transformation that the American mortgage market went through,, arguing that such changes gain renewed vigor and are only completed with the rise and growth of credit default swaps (CDS) and synthetic CDOs, that were fundamental to the maintenance of low interest rates on mortgages, thus contributing directly to the bubble in the property market that resulted in the economic crisis.

Keywords: Derivatives; Crisis; Subprime; Marx; Fourth dimension; Real estate market; Mortgages.

JEL E440, B510, G010.

\section{Introdução}

Muitos estudos têm sido produzidos com o objetivo de analisar e interpretar o papel dos novos produtos financeiros na geração e propagação da crise financeira das hipotecas subprime. O objetivo deste artigo é construir uma explicação alternativa para compreender a crise de 2007/2008. Nesta interpretação, o papel das inovações financeiras no mercado de crédito imobiliário é central, sendo analisado dentro de um quadro sistêmico mais amplo das etapas do capitalismo. Busca-se ilustrar, para o caso particular do mercado de crédito

\footnotetext{
*Artigo recebido em 30 de agosto de 2014 e aprovado em 13 de abril de 2018.

${ }^{* *}$ Professor doutor do Instituto de Economia da Universidade Estadual de Campinas (IE/Unicamp), Campinas, SP, Brasil. E-mail: guil.mello@gmail.com.
} 
imobiliário nos EUA, como se deu o processo de desenvolvimento das formas do capital financeiro, analisando as transformações sofridas por este mercado sob a ótica das "dimensões do capitalismo"".

Para isso, o artigo se divide em três partes. Primeiramente, busca apresentar os elementos sistêmicos do que aqui se denomina quarta dimensão, uma nova "modalidade" capitalista onde o mercado de derivativos ganha proeminência como locus da valorização e precificação do capital. Nesta seção, apresenta-se sumariamente o conceito de dimensões do capitalismo e seu desenvolvimento teórico, conforme abordado em trabalhos anteriores, caracterizando particularmente o que distingue a "quarta dimensão" das anteriores. A segunda seção busca pensar a evolução do mercado de crédito imobiliário sob a égide do desenvolvimento das formas e das dimensões do capitalismo, desde o capital a juros até os derivativos. Em um terceiro momento, procura-se descrever as transformações promovidas pelos derivativos e pelas inovações financeiras na dinâmica do mercado imobiliário norteamericano. Conclui-se que a crise dos mercados financeiros, em particular do mercado imobiliário, é fruto de seu sucesso: exatamente por que foram bem-sucedidos em levar à exasperação os movimentos que lhe são impostos pelo processo concorrencial, se adequando à forma mais desenvolvida e bem acabada do capitalismo atual (o derivativo), criou-se uma profunda fragilidade financeira ancorada nas relações alavancadas de débito e crédito assumidas nos períodos anteriores, que se desfizeram com a súbita reversão das expectativas.

\section{As quatro dimensões e o capitalismo contemporâneo ${ }^{2}$}

Para melhor compreender a lógica sistêmica do arranjo particular de capitalismo que entrou em crise, utiliza-se aqui a construção teórica das "dimensões do capitalismo". As quatro dimensões são construções analíticas que buscam descrever a formação e o desenvolvimento do modo de produção capitalista, analisando a transfiguração das formas, ou seja, como as formas mais complexas de acumulação do capital surgem do seio das formas mais elementares através de suas contradições, passando a subordiná-las e transformar a dinâmica e o funcionamento do capitalismo. O objetivo dessa construção é destacar o mercado de derivativos como um desdobramento do capital fictício e como uma esfera particular da acumulação financeira. Há três eixos metodológicos utilizados para caracterizar cada uma das dimensões. O primeiro é a análise marxista das formas de circulação do dinheiro e das relações de subordinação no processo de acumulação capitalista. O segundo eixo parte da análise de Bryan e Rafferty (2006) que identificam graus de separação na propriedade do capital no processo de acumulação capitalista. Já o terceiro eixo de análise é a descrição da lógica do sistema e das transformações no capitalismo em cada uma das dimensões.

(1) O conceito de dimensões do capitalismo, que será brevemente revisitado na seção 2 deste artigo, foi desenvolvido em conjunto por diversos pesquisadores do Instituto de Economia da Universidade Estadual de Campinas (Unicamp), tendo como resultado a produção de dois artigos e uma tese de doutorado. Para maiores informações sobre o conceito e suas decorrências, ver Carneiro, Rossi, Mello e Chiliatto-Leite (2015), Carneiro, Rossi, Mello e Chiliatto-Leite (2014) e Mello (2013).

(2) Esta seção foi adaptada da seção 2 do artigo de Carneiro, Rossi, Mello e Chiliatto-Leite (2015). 
As quatro esferas apresentadas não estão necessariamente associadas a um contexto histórico específico, coexistindo historicamente ${ }^{3}$. Destaca-se também que a separação analítica das esferas de acumulação não implica em independência entre elas. Tampouco as relações de subordinação entre as finanças e a produção implicam em relações de autonomia absoluta da primeira ante a segunda. Ou seja, não há um processo de valorização auto-referenciado onde as finanças determinam ilimitadamente seu próprio valor. Pelo contrário, a relação de subordinação sugerida não isenta a dependência da esfera financeira com relação à esfera da produção, essas são esferas inter-condicionadas. Nesse sentido, os descolamentos potenciais entre as esferas são limitados temporalmente e serão recorrentemente ajustados por meio de crises.

A categoria analítica da primeira dimensão refere-se à forma mais primitiva de circulação mercantil, devido à natureza da troca ocasional cujo objetivo é a obtenção de valores de uso. Isto é o que Marx (1985) chama de "a forma direta de circulação de mercadoria", um tipo abstrato de circulação de mercadorias. Isto significa que Marx mostra a maneira em que, numa sociedade mercantil simples (hipotética) - com negociação de commodities e onde o dinheiro não tem nenhum papel como capital -, os valores ou produtos do trabalho humano são trocados de acordo com o esquema: mercadoria (M) - dinheiro (D) - mercadoria (M). Nesta esfera, o dinheiro é um meio de circulação e não o fim do processo. É importante salientar que, nesta esfera de circulação não há nenhuma separação entre o trabalho e a posse dos meios de produção. A lógica do processo é obter um novo bem, ou seja, a produção de uma mercadoria que tem valor de uso como seu fim ${ }^{4}$.

A segunda dimensão é uma esfera de acumulação produtiva onde o objetivo é começar com uma quantia de dinheiro e, mediante o processo D-M-D", acabar com um aumento de $\Delta \mathrm{D}$, ou seja, um $\mathrm{D}^{\prime}=\mathrm{D}+\Delta \mathrm{D}$, este último gerado na esfera da produção. $\mathrm{O}$ dinheiro adicional da segunda dimensão é o lucro obtido a partir da mais-valia que resulta do processo de produção. Uma condição prévia para a segunda dimensão é ter estabelecido as relações capitalistas de produção. Bryan e Rafferty (2006) referem-se à separação do trabalhador de seus meios de produção como o "primeiro nível de separação da posse do capital". Esta separação permite a formação de uma classe de proprietários capitalistas e outra de trabalhadores "livres", disponíveis no mercado, de maneira que a segunda dimensão é marcada pela subsunção do trabalho ao capital, que por sua vez manifesta-se na relação salarial. Além disso, as decisões

(3) Por se tratar de uma construção lógico-analítica, o conceito de "dimensões” não busca captar as transformações das formas concretas que o capitalismo assume em suas diversas configurações temporais e regionais/nacionais. Na prática, é o desenvolvimento e hegemonia de cada dimensão em determinado contexto histórico que permite uma análise da situação concreta de um país ou região, já que o papel das finanças e particularmente dos derivativos vão se alterando e ganhando ou perdendo proeminência, dependendo dos arranjos institucionais particulares que os limitem. Como construção lógico-abstrata, o conceito de dimensões busca analisar a mudança nas formas da riqueza e sua interação contraditória com as formas mais simples, não podendo ser automaticamente traduzido para realidades histórico/locais concretas, exigindo uma série de mediações e qualificações caso se queira analises de um caso concreto.

(4) Não é o propósito deste trabalho discutir a teoria do valor de Marx. Presume-se que o leitor tenha uma compreensão básica sobre esta questão. 
de produção são individuais e têm como objetivo a obtenção de dinheiro adicional e, especificamente, a valorização do capital que envolve o dinheiro como um fim.

Além disso, a constante necessidade de valorização do capital já se manifesta na segunda dimensão. A circulação de dinheiro como capital significa que o objetivo não é obter valores de uso, mas obter lucros, e o processo de valorização é um fim em si. Em resumo, na segunda dimensão, o processo começa com uma quantia de dinheiro e termina com um aumento do dinheiro original, que é possível pela subordinação do trabalho ao capital e pela criação de mais-valia. Portanto, na chamada segunda dimensão, dinheiro se torna capital e acumulação é configurada como um processo de acumulação de riqueza abstrata, de dinheiro.

O primeiro elemento da terceira dimensão, por sua vez, é a ocorrência de valorização do capital sem a mediação da produção de mercadorias, de maneira que a circulação é reduzida aos extremos D-D'. O circuito D-D' aparece, dentro da segunda dimensão, como forma de apoiar a acumulação produtiva. Isto significa que o crédito, entendido como a transferência temporária do capital entre capitalistas, nasce como uma forma de ampliar a capacidade de mobilizar a força de trabalho e os meios de produção. Além do capital portador de juros, Marx (2001) traz os primeiros elementos para a compreensão do que chama de "capital fictício". A constituição de instrumentos financeiros negociáveis - tais como títulos, letras de câmbio, ações - são formas de capital fictício, com um valor de face original, mas cujo valor corrente corresponde aos fluxos de rendimentos esperados descontados por uma taxa de juros. Aqui o processo de valorização do capital fictício ganha autonomia aparentemente completa em relação à valorização produtiva. Portanto, a terceira dimensão apresenta o "segundo nível de separação de posse do capital" (Bryan; Rafferty, 2006), que é a separação de propriedade e produção (ou gestão) - resultante da propriedade de ações.

Vasta literatura com fundamentação teórica sobre as contribuições de Marx e Keynes descreve o domínio de finanças no processo econômico e as mudanças no capitalismo contemporâneo. Autores tais como Chesnais (1995; 1996; 2003; 2005), Epstein (2001), Belluzzo (1997), Tavares (1997), Plihon (2004), Aglietta e Rebérioux (2005), Aglietta (2006), Carneiro (2007), Palley (2007) e Guttmann (2008) promovem a ideia de dominância financeira, capitalismo dominado pelas finanças, ou simplesmente "financeirização". Essa literatura descreve a lógica principal da terceira dimensão, que é a lógica de valorização de ativos ou valorização fictícia. Em linhas gerais, a dinâmica dos ganhos de capital impõe seus interesses e controla o comportamento do circuito D-M-D’e, portanto, subordina a esfera da produção a seus interesses.

(5) Não é o objetivo deste trabalho apresentar as diversas visões acerca do fenômeno da financeirização, suas origens e interpretações, bastando salientar que em todas as definições encontradas nos trabalhos citados coloca-se como ponto central a lógica de valorização fictícia, através da apreciação do estoque de capital, em detrimento da lógica de valorização "produtiva" e de seus fluxos produzidos. Para um panorama dos diferentes conceitos e abordagens sobre o conceito de financeirização, ver Van Der Zwan (2014). 
$\mathrm{Na}$ maior parte da literatura sobre financeirização, os derivativos aparecem tangencialmente, ilustrando o modo de funcionamento de empresas cuja centralidade está na lógica de valorização de ativos representada pelo mercado de ações. Portanto, o debate não é centrado no mercado de derivativos, mas sim no reino da propriedade, onde o capitalismo se move por meio da centralização da riqueza, de fusões e aquisições, da valorização das ações etc. É baseado neste aspecto que este trabalho propõe uma contribuição e argumenta que os derivativos desempenham um papel mais estrutural no processo de acumulação de capital.

\subsection{A quarta dimensão do capitalismo - o papel dos derivativos}

$\mathrm{Na}$ física, a discussão sobre a quarta dimensão surge como uma tentativa de usar o tempo nos estudos de fenômenos naturais. Sabe-se que o espaço possui três dimensões, descritas por três planos ortogonais que compõem um sistema de coordenadas tridimensional. $\mathrm{Na}$ física moderna, o conceito de espaço-tempo tornou-se amplamente utilizado com a elaboração da teoria da relatividade. O tempo aparece como uma dimensão adicional para descrever o movimento dos corpos e dos fenômenos naturais. Em economia, os derivativos referem-se a riscos associados à passagem do tempo, ou melhor, buscam reduzir a incerteza econômica a riscos probabilísticos e os negociam em um determinado mercado. Para o agente que procura proteção (hedge), os derivativos representam uma tentativa de mitigar a incerteza em torno do processo de reprodução do capital. Eles são, portanto, uma redução da incerteza keynesiana no nível microeconômico. Para aqueles que especulam, o tempo é um fator determinante na obtenção de ganhos ou perdas. A lógica da especulação é uma lógica temporal no sentido da antecipação do movimento dos preços ou a ocorrência de eventos futuros ${ }^{6}$.

Os derivativos são usualmente definidos nos manuais de finanças como instrumentos financeiros que estabelecem pagamentos futuros, cujo montante deriva da variação de valor de um ativo ou da possibilidade de ocorrência de um evento determinado. Esta definição é pouco precisa, pois estabelece um nexo causal que nem sempre se verifica na realidade: em diversos mercados, os preços dos ativos e dos derivativos se determinam mutuamente. Em outros, esta relação se inverte totalmente: são os derivativos que determinam os preços dos ativos, e não o contrário.

(6) De acordo com Schackle (1959, p. 285): “O matemático trata o tempo como um espaço, ou como uma dimensão de um espaço, em que todos os pontos têm igual status ou importância ou validade juntos, dentro de uma mesma perspectiva do mundo. Eles têm, como digo paradoxalmente, uma validade simultânea, cada um deles significa o mesmo para ele quando pensa em todos eles em um único pensamento". A tentativa da forma derivativo é tratar o tempo como o matemático faz, quando os derivativos quantificam a incerteza sobre as mudanças de preços, ou a incerteza sobre a ocorrência de qualquer evento, em um "risco" medido. A incerteza é reduzida a um "risco" supostamente conhecido, como se fosse previsível. Essa "contradição" da forma derivativo é precisamente a razão pela qual eles são propensos a cometer erros e a amplificar a volatilidade. Para os propósitos deste trabalho, é importante explicar claramente o significado de incerteza, que não pode ser confundida com o risco probabilístico. A incerteza significa que há eventos no decurso das atividades econômicas em que não há conhecimento probabilístico de seus resultados. Há eventos cujos efeitos simplesmente não são quantificáveis, ou mesmo desconhecidos, em um mundo onde o passado não é invariavelmente repetido e o futuro é necessariamente incognoscível. 
Uma segunda característica ressaltada é que uma operação de derivativo, considerada isoladamente, representa um "jogo de soma zero", onde os ganhos são iguais às perdas ${ }^{7}$. No entanto, como afirmam Bryan e Rafferty (2006, p. 42), o mercado de derivativos pode produzir uma soma positiva, ao gerar efeitos dinamizadores sobre a alocação de recursos e o processo de acumulação. Além disso, conforme argumentam Carneiro; Rossi; Mello e Chilliato-Leite (2015), do ponto de vista macroeconômico, a capacidade do mercado de derivativos de precificar determinados ativos e promover oportunidades de arbitragem entre os mercados futuro e à vista abrem espaço para ganhos de todos os agentes envolvidos, ao menos até um eventual estouro da bolha de ativos formada no processo ${ }^{8}$.

Os mercados de derivativos podem se apresentar com diferentes configurações e seus agentes com motivações diversas. Do ponto de vista dos mercados, eles podem ser com entrega física ou com liquidação em moeda; organizados (com clearing central) ou de "balcão", onde as operações são bilaterais entre investidores privados. Do ponto de vista da motivação dos agentes, além do desejo de realizar "hedge", os investidores podem realizar operações de arbitragem entre diferentes mercados e ativos e especular com ativos através dos mercados de derivativos.

Quatro características diferenciam este novo instrumento financeiro dos demais presentes nas outras dimensões do capitalismo. A primeira das três características centrais dos derivativos é o fato de que a posse deste não implica em participação na propriedade do bem subjacente. Fundamentalmente, um derivativo é uma aposta na variação de preço de um ativo, sem haver a necessidade de posse do ativo sobre o qual está se apostando. Bryan e Rafferty (2006) se referem a esta separação como sendo o terceiro grau de separação da propriedade do capital, e assim definem:

O terceiro grau de separação da posse de capital envolve o processo pelo qual a propriedade do capital é separada da propriedade da empresa e o capital concorre consigo próprio. Já descrevemos essa separação em sua forma mais óbvia: que a posse de um derivativo de ação (contrato de opção ou futuros) é diferente da posse da ação em si. O derivativo de uma ação (por exemplo, um contrato de futuros sobre o índice de mercado ou uma empresa) dá a seu proprietário uma exposição sobre o desempenho (preço e

(7) "Mercados virtuais não criam riqueza, apenas a redistribuem entre os participantes. No agregado, só se pode ganhar, nos mercados de derivativos, os valores perdidos por outros participantes. A única riqueza criada nesses mercados é constituída pelas corretagens e emolumentos às Bolsas pagos por todos os participantes, quer tenham ganhado ou perdido dinheiro em suas operações" (Farhi, 1998, p. 7).

(8) "In this sense, despite the zero sum game argument, when considering the derivative operation not as an isolated contract, but rather as part of a bigger chain of financial operations that interconnect futures markets to spot markets, the price cycles resulting from speculation in the derivatives markets can provide gains to different financial agents involved. The greater the distortions caused by derivatives in prices, the broader are the opportunities created for arbitrage and the greater are the appropriation of gains. Furthermore, the cycles of appreciation of assets à la Minsky can generate and enhance financial bubbles that potentiate the creation of financial wealth, at least before an eventual bubble burst" (Carneiro; Rossi; Mello; Chiliatto-Leite, 2015). 
rentabilidade) da empresa (ou grupo de empresas) de uma forma que é mais flexível do que a participação acionária direta (Bryan; Rafferty, 2006, p. 74, tradução livre).

Outra característica central dos derivativos é sua capacidade de conectar o presente ao futuro, o que Bryan e Rafferty (2006) chamam de binding. Os preços presentes e os preços futuros dos ativos se inter-relacionam de maneira mais direta agora. Algumas operações com derivativos buscam reduzir de tal forma a dimensão temporal das apostas, que eliminam, do ponto de vista microeconômico, grande parte dos riscos e incertezas associados à passagem do tempo. Um exemplo disto pode se encontrar nas operações de arbitragem, onde o risco de preço associado à passagem do tempo é virtualmente eliminado (Lipuma; Lee, 2005, p. 411 e 420). Nestas operações, o agente arbitrador assume posições diametralmente opostas nos mercados à vista e de derivativos, eliminando assim o risco de variação de preço no tempo e garantindo um ganho líquido e certo para o arbitrador. Do outro lado da operação de derivativo, podemos encontrar, por exemplo, um agente especulador, que busca seu ganho apostando na variação do preço dos ativos no tempo.

A terceira característica a se ressaltar dos derivativos financeiros é o fato de eles integrarem os diversos mercados, possibilitando que os diferentes ativos financeiros sejam mensurados sob uma mesma unidade de medida monetária. Esta característica, a que Bryan e Rafferty (2006) se referem como blending (aqui traduzido como "transversalidade"), traz consigo inúmeros aspectos relevantes dos mercados de derivativos. $\mathrm{O}$ fato de eles serem capazes de comensurar os diferentes ativos está diretamente relacionado à capacidade dos derivativos de "commoditizar os riscos", ou, como afirmam Lipuma e Lee (2005), "objetificar o risco abstrato".

Por fim, a quarta característica que diferencia a forma derivativo das demais aqui estudadas é a natureza diferenciada do ganho financeiro advindo destas operações. Conforme a abordagem marxista, o capital tem o poder de lucrar com a produção e apropriação da maisvalia. Por sua vez, o dinheiro é crucial, porque move o processo de produção e gera riqueza adicional. Ou seja, o dinheiro entra no circuito como capital, passa pelo processo de produção e retorna ao capitalista sob a forma de capital monetário no final do processo. O dinheiro é, portanto, o meio e o objetivo do processo. Com o capital portador de juros e fictício, o capitalismo assume uma forma mais exterior e mais fetichista. $\mathrm{O}$ dinheiro-capital ganha uma autonomia aparente e relativa para seguir seu caminho para a apreciação por conta própria. Pode ser capital portador de juros, apoiado pelo sistema de crédito, que aparentemente fornece dinheiro com a capacidade de criar riqueza ou agregar valor a si mesmo, independentemente da produção; ou capital fictício, em que ações de riqueza podem aparentemente apreciar de forma autônoma. Assim, a financeirização permite que a forma D-D' subordine a produção e o trabalho.

Agora, a nova forma de acumulação fornecida pelos mercados de derivativos tem uma característica fundamental: o processo de valorização é independente do investimento inicial. Nesta fase, o capital assume sua forma mais abstrata. Se anteriormente a fórmula para a 
valorização do capital poderia ser indicada por D-D', onde $D^{\prime}=\mathrm{D}+\Delta \mathrm{D}$, na esfera dos derivativos, propõe-se que a forma de valorização do capital possa ser simplesmente denotada por $\Delta \mathrm{D}^{*}$. A notação $\Delta \mathrm{D}^{*}$ sugere, por um lado, a falta de capital anterior (D) e, por outro lado, a forma $(*)$ denota a diferença na natureza do ganho da operação.

Ao contrário das formas anteriores, $\Delta \mathrm{D}^{*}$ "dispensa" a necessidade de dinheiro como meio de apreciação, ou seu adiantamento no início do processo ${ }^{9}$. Isso significa que o dinheiro ainda é um fim do processo de valorização, mas aparentemente perde sua relevância como veículo de valorização, bem como o sistema de crédito ${ }^{10}$. A alavancagem, uma característica dos mercados de derivativos, não implica relações de crédito como tal, mas estas estão implícitas no conceito de alavancagem. Essas relações, bem como os juros associados à forma dinheiro, são incorporados no preço dos contratos de derivativos. O preço futuro de qualquer ativo é dado não só pelas expectativas dos agentes quanto à mudança de preço desse ativo, mas pela taxa de juros do mercado de crédito, que consiste em um custo de carregamento desse contrato.

É importante ressaltar que derivativos não são exclusivos da quarta dimensão do capitalismo nem são uma invenção das finanças modernas ${ }^{11}$. O que muda a partir dessa nova dimensão é o papel exercido por esse instrumento, a motivação dos agentes e sua função dentro do sistema de valorização do capital. Esses instrumentos emergem organicamente do processo de produção e podem ser observados em cada uma das quatro dimensões. Na primeira dimensão, os derivativos são inseridos para garantir a circulação de commodities a um preço determinado, isto é, garantir vendas futuras ou futuras compras a um preço preestabelecido, garantindo proteção contra variação de preço na troca de mercadorias. Os derivativos também são funcionais na lógica da acumulação produtiva, caracterizada neste estudo como segunda dimensão. Eles podem aparecer em vários estágios de produção de commodities, tais como assegurar o preço de compra de matérias-primas e insumos, comprar seguro contra eventos que

(9) Nos mercados de balcão (OTC), o requisito de margem de segurança fica a critério das partes envolvidas no contrato; enquanto isso, no mercado de ações, há exigências de margem, uma vez que a liquidação do contrato é garantida por uma contraparte central. Nestes mercados de derivativos altamente desregulados, a necessidade de capital anterior é muito baixa ou inexistente. Assim, os derivativos são instrumentos utilizados para evitar uma regulamentação prudencial, uma vez que um contrato de derivativos pendente não afeta de imediato os ativos das empresas (já que o pagamento do contrato é diferido no tempo, ocorrendo apenas no momento de sua liquidação); além de nem sempre aparecer em seu balanço. Pode-se fazer apostas sem a necessidade de depósitos de garantia, o que encoraja os agentes a entrar nesses mercados altamente alavancados. Além disso, o crescimento dos mercados de balcão permite um aumento nos volumes de negociação em mercados de derivativos.

(10) Ou seja, não há necessidade de transformar dinheiro em capital para o processo de valorização. O dinheiro, bem como a relação de propriedade e crédito, está "escondido" em operações de derivativos. A precificação de um contrato futuro se dá tanto pelas expectativas de valorização/desvalorização do ativo de referência quanto pelo custo de oportunidade representado pela taxa de juros do mercado de crédito. Isso não implica dizer que o investidor precisou tomar crédito para adentrar na operação, mas significa que a remuneração da forma dinheiro (os juros) estão embutidos no preço deste contrato. Por isso se diz que o sistema de crédito perde importância como "veículo", mas que suas relações são incorporadas ao preço dos contratos.

(11) De acordo com Bryan e Rafferty (2006), há registros de contratos futuros de arroz na China em 2000 a.c. A função original destes instrumentos era proteger os agricultores das flutuações dos preços agrícolas. Os derivados são, portanto, instrumentos que emergem organicamente do processo de produção e são posteriormente apropriados e recondicionados pelo sistema financeiro para melhorar o processo de acumulação de capital. 
interferem no processo de produção ou garantir o preço final do produto. Essas ocorrências atenuam as incertezas associadas ao processo de produção e aumentam a previsibilidade dos ganhos resultantes desse processo $(\Delta \mathrm{M})$.

Na terceira dimensão, os derivativos são utilizados principalmente para garantir a rentabilidade do capital, porque as relações de crédito, títulos e mercados de ações são permeadas pela incerteza relacionada às mudanças em diversos preços relativos (taxas de juros, câmbio, etc.) e a duração dos contratos de crédito. No entanto, a partir do desenvolvimento do capital fictício e o consequente aumento da importância dos mercados secundários, surge o crescimento e a generalização do uso especulativo dos mercados de derivativos. Essa generalização dá origem à quarta dimensão, onde a forma derivativo torna-se dominante em relação às formas anteriores de valorização do capital.

Marx estabelece como as contradições na dimensão anterior resultam na transição para a forma posterior. Isso significa que o desenvolvimento do capitalismo é um processo permanente que busca novos arranjos e mecanismos mais eficientes para valorizar o capital, ao mesmo tempo em que cria novas contradições na própria acumulação de capital. Seguindo esta construção, a forma derivativo é resultado da dinâmica contraditória do desenvolvimento das dimensões anteriores.

No nível lógico, a forma derivativo surge das formas anteriores e tradicionais de acumulação de capital (capital produtivo, capital a juros e capital fictício) porque é uma maneira de negociar os resultados futuros do processo de acumulação $(\Delta \mathrm{M} *)$, conforme discutido abaixo. Além disso, é uma forma mais eficiente de servir o capital especulativo, tendo em conta as características institucionais dos derivativos, como a maior capacidade de alavancagem, o fácil acesso aos mercados e que não há necessidade de transportar ou entregar o ativo negociado.

Ao nível histórico, a quarta dimensão se desenvolve simultaneamente com o capital em sua forma monetária e, progressivamente, constitui uma força autônoma no processo de valorização do capital quando os mercados profundos e líquidos negociam livremente estoques de riqueza. Portanto é apenas depois da década de 1970 que o papel dos derivativos começa a mudar, juntamente com as transformações do sistema financeiro e monetário internacional que introduzem progressivamente novas e mais eficientes formas de acumulação de capital, que aumentam a importância dos mercados de valores mobiliários e o papel dos investidores financeiros na dinâmica da economia. Desta maneira, pode-se dizer que a quarta dimensão está ligada ao processo de financeirização.

A forma derivativo, dialeticamente, depende da circulação de capital fictício e, ao mesmo tempo, nega-a. Depende, porque sua forma de ganho está diretamente relacionada à variação de preço do capital fictício, mas a nega porque o intercâmbio de derivativos tende a ser independente das mudanças nos direitos de propriedade. Finalmente, reforça o papel do capital fictício e amplifica seu impacto na acumulação de capital. 
Além disso, os instrumentos de derivativos são capazes de aprofundar a abstração das relações sociais já presentes em capital fictício e portador de juros (típicos da terceira dimensão $)^{12}$. Assim, se a terceira dimensão significou o empoderamento da acumulação financeira em relação às bases reais da valorização do capital, a quarta dimensão avança neste processo e consolida a forma "acumulação financeira", tornando-a ainda mais autônoma, abstrata e, portanto, fetichizada. Afinal, os derivativos são instrumentos que permitem que o capital se reproduza por um processo que "dispensa" a propriedade do imobilizado e o próprio dinheiro como meio. $\mathrm{O}$ fetiche toma o seu desprendimento mais radical das formas concretas, uma vez que as operações de derivativos escondem ativos reais por trás do contrato, bem como as relações sociais que dele decorrem.

No entanto, essa abstração não implica a autonomia absoluta dos mercados de derivativos. Esses mercados facilitam os movimentos de preços dos ativos, tanto em tempos de boom quanto em tempos de crise, que são transmitidos à esfera real e afetam relações de crédito e relações de propriedade. A acumulação de capital promovida por meio de derivativos encontra seu "limite" em momentos críticos, ou seja, quando as mudanças na percepção de risco dos agentes geram ajuste de preços no mercado, que assumem a forma de inversão de apostas e liquidação de contratos. Neste momento, as relações sociais de propriedade e crédito são novamente essenciais para garantir a liquidez e a solvência dos agentes envolvidos nesses mercados, revelando as reais relações sociais de poder, propriedade e dinheiro que apareceram anteriormente apenas de forma velada.

A natureza dos ganhos na quarta dimensão é diferente da fornecida nas dimensões anteriores. Como visto, o ganho obtido pelo capitalista na segunda dimensão é o lucro derivado da mais-valia, e o ganho na terceira dimensão se origina da valorização dos ativos ou do recebimento de juros. Agora, o ganho em uma transação de derivativos pode ser considerado um ganho de "cassino"13, ou seja, um ganho decorrente da mera aposta no movimento de preços por um ativo que o agente apostador não possui ${ }^{14}$. Os ganhos nesses mercados são proporcionados pela especulação, conduzida entre os principais atores do mercado, que se manifesta sob a forma de estratégias consolidadas, visando manipular informações e formar convenções que têm o poder de distorcer os preços. O empoderamento do mercado de derivativos também é a autonomização da especulação sobre os direitos de propriedade. Assim, como proposto por Lipuma e Lee (2005), os derivativos são uma forma funcional de capital especulativo por excelência.

(12) Blackburn (2006), ao cunhar o termo "capitalismo cinza", chama a atenção para essa característica de dissociação da propriedade de ativos da negociação de suas flutuações de preços, bem como a "opacidade" (Mckenzie, 2011, p. 209) das relações sociais que são subjacentes a cada ativo. Ou seja, as relações de propriedade e responsabilidade são "nubladas" pela complexidade das transações financeiras.

(13) Seguindo aqui a nomenclatura utilizada por Strange (1986) e McKenzie (2011) que, ao descrever o estado atual do capitalismo financeiro, o denominam de "Casino Capitalism".

(14) Vale ressaltar que o ganho pode resultar da apreciação ou desvalorização dos estoques de capital, ou seja, o preço decrescente do ativo subjacente pode gerar ganhos, desde que a aposta tenha sido feita na direção certa. 
O Quadro 1 resume o argumento analítico desenvolvido em todo o texto sobre a consolidação das dimensões e suas principais características.

Quadro 1

As quatro dimensões do capitalismo

\begin{tabular}{|c|c|c|c|c|}
\hline & $\begin{array}{c}\text { Circulação do } \\
\text { dinheiro }\end{array}$ & $\begin{array}{c}\text { Relações de } \\
\text { propriedade }\end{array}$ & $\begin{array}{c}\text { Relações de } \\
\text { subordinação }\end{array}$ & Lógica do sistema \\
\hline $\begin{array}{c}1^{\circ} \text { DIMENSÃO } \\
\text { Esfera das } \\
\text { mercadorias }\end{array}$ & M-D $-\mathrm{M}$ & $\begin{array}{c}\text { Produtor possui os } \\
\text { meios de produção }\end{array}$ & Subsistência \\
\hline $\begin{array}{c}2^{\circ} \text { DIMENSÃO } \\
\text { Esfera da produção }\end{array}$ & $\mathrm{D}-\mathrm{M}-\mathrm{D}^{\prime}$ & $\begin{array}{c}\text { Separação entre } \\
\text { trabalho e } \\
\text { propriedade dos } \\
\text { meios de produção }\end{array}$ & $\begin{array}{c}\text { Subordinação do } \\
\text { trabalho ao capital }\end{array}$ & $\begin{array}{c}\text { Lucro por meio da } \\
\text { extração de mais } \\
\text { valia }\end{array}$ \\
\hline $\begin{array}{c}3^{\circ} \text { DIMENSÃO } \\
\text { Esfera da } \\
\text { propriedade }\end{array}$ & $\begin{array}{c}\text { Separação entre a } \\
\text { propriedade da } \\
\text { companhia e a } \\
\text { gerência da } \\
\text { produção }\end{array}$ & $\begin{array}{c}\text { Subordinação do } \\
\text { capital produtivo } \\
\text { ao capital } \\
\text { financeiro }\end{array}$ & $\begin{array}{c}\text { Valorização } \\
\text { patrimonial }\end{array}$ \\
\hline $\begin{array}{c}4^{\circ} \text { DIMENSÃO } \\
\text { Esfera dos } \\
\text { derivativos }\end{array}$ & $\Delta \mathrm{D}^{*}$ & $\begin{array}{c}\text { Separação entre a } \\
\text { propriedade dos } \\
\text { ativos e a } \\
\text { propriedade sobre a } \\
\text { performance dos } \\
\text { ativos }\end{array}$ & $\begin{array}{c}\text { Subordinação da } \\
\text { esfera da produção } \\
\text { à esfera dos } \\
\text { derivativos }\end{array}$ & $\begin{array}{c}\text { Ganhos de } \\
\text { aposta/cassino }\end{array}$ \\
\hline
\end{tabular}

Fonte: Elaborado pelo autor. Apresentado anteriormente em Carneiro; Rossi; Mello e Chiliatto-Leite (2015).

Como resultado da transversalidade - juntamente com alta alavancagem e aumento no volume de transações - a dinâmica dos mercados de derivativos gera uma constante repreciação dos estoques de ativos financeiros e, portanto, da riqueza fictícia. Os mercados de derivativos tornam-se a locomotiva da valorização da riqueza quando assumem a prerrogativa da formação de preços. Neste ponto, a quarta dimensão se consolida como uma forma hierarquicamente superior de acumulação de capital, já que alguns dos principais mercados à vista tornam-se dependentes dos mercados de derivativos e a variação de preços é transmitida por arbitragem na direção oposta ao habitual (ou seja, do futuro para o à vista). À medida que o reflexo se torna a imagem, pode-se dizer, de forma contraditória, que os preços à vista são "derivados" dos preços futuros ${ }^{15}$.

Aqui vem uma contradição fundamental que consolida o desenvolvimento da quarta dimensão. Ao mesmo tempo em que o derivativo é uma expressão do processo produtivo e fictício de acumulação de capital, o movimento de D-D' e a acumulação de capital como um todo começam a ser influenciados por derivativos. Como resultado, enquanto os derivativos

(15) Para exemplos concretos de mercados em que os derivativos assumem a função de precificação do mercado a vista, ler a seção 4 de Carneiro; Rossi; Mello e Chiliatto-Leite (2015). 
utilizados como hedge podem reduzir a incerteza microeconômica, a generalização do seu uso especulativo, a capacidade de influenciar os preços à vista e a característica de transversalidade aumentam a volatilidade dos preços, a instabilidade macroeconômica, os riscos sistêmicos e podem criar condições para uma profunda crise financeira.

Em conclusão, a quarta dimensão se consolida quando a lógica do lucro por apostas, em mercados com alta liquidez, alta alavancagem e abstração profunda, é capaz de precificar alguns dos bens e ativos principais do sistema capitalista. Assim, o mercado de derivativos começa a assumir cada vez mais o papel de locus privilegiado de movimento, precificação e valorização do capital fictício, subordinando a lógica de valorização das dimensões anteriores.

\section{As quatro dimensões e o mercado imobiliário}

O desenvolvimento da estrutura do mercado imobiliário pode ser entendido dentro do panorama analítico e conceitual das quatro dimensões do capitalismo, desde que realizadas as devidas mediações. A reconstrução do objeto de estudo (o mercado imobiliário) deve partir de suas formas mais elementares para chegar-se ao fim ao mercado plenamente constituído em suas quatro dimensões, passando anteriormente por cenários hipotéticos de um mercado sem capital (primeira dimensão) ou um mercado sem crédito (segunda dimensão). A reconstrução histórica propriamente dita só pode se iniciar quando já existe o mercado em sua forma completa, atuando em sua plena capacidade por meio do processo de concorrência, acumulação, centralização e concentração de capital, características típicas da terceira dimensão. Assim sendo, a reconstituição de cenários hipotéticos da primeira e segunda dimensão não pode ser pensada dentro de um quadro histórico, mas sim como construções analíticas que nos legam elementos fundamentais para a compreensão do mercado plenamente constituído.

De início, é possível imaginar um cenário hipotético onde a construção do imóvel seja realizada para uso próprio, não se configurando necessariamente como mercadoria. Neste caso hipotético, o produtor individual venderia as mercadorias que produz (M) para angariar dinheiro (D) com a finalidade de comprar material (M) para construir seu imóvel, completando assim o circuito $\mathrm{M}-\mathrm{D}-\mathrm{M}$. O imóvel serve ao produtor como valor-de-uso, como meio de sobrevivência, não como mercadoria a ser comercializada. Nesta hipótese, típica do que aqui se denominou primeira dimensão, não é possível falar em "mercado" imobiliário, muito menos de capital. O imóvel é apenas uma mercadoria em potencial, mas não foi produzida com este objetivo, sendo sua utilidade como valor-de-uso o que o caracteriza.

A segunda forma como se pode encarar a produção imobiliária é aquela em que o imóvel é produzido como mercadoria, ou seja, produzido não para usufruto pessoal, mas sim para venda no mercado imobiliário. Neste caso, o produtor do imóvel está no circuito $\mathrm{D}-\mathrm{M}-$ D’, ou seja, seu objetivo é acumular valor na forma abstrata ao final do processo de produção e circulação da mercadoria em questão. Para isso, ele se utiliza de uma massa de capital prévio $^{16}$ para contratação de mão de obra e compra de materiais que, ao final, produziram a

(16) Como estamos nos referindo unicamente à segunda dimensão, o crédito ainda não está embutido neste caso hipotético, precisando o produtor lançar mão de capital previamente acumulado. 
mercadoria “imóvel”. Esta mercadoria, por sua vez, será revendida no mercado imobiliário, garantindo ao "produtor" do imóvel um $\Delta \mathrm{D}$ oriundo da mais-valia extraída do trabalhador ao longo do processo produtivo. No entanto, apesar de já se poder falar em mercado imobiliário, esta situação hipotética ainda não contempla o mercado na sua forma mais bem acabada, onde prevalecem as forças da concorrência e do crédito.

O mercado imobiliário apenas toma forma completa com a constituição do mercado de crédito imobiliário, pois ele impulsiona sobremaneira a demanda pelos imóveis, garantindo maior liquidez e profundidade aos imóveis, assim como desvelando as forças centrais da concorrência e da inovação, típicas do capitalismo plenamente constituído. Apenas com o advento do crédito se torna possível aventar a possibilidade de "bolhas" imobiliárias, pois a criação de um verdadeiro mercado imobiliário possibilita a especulação com o preço dos ativos, que se tornam fonte de ganhos extraordinários dos investidores, advindos da valorização de terrenos e imóveis. As interconexões desta dimensão com a anterior são íntimas, tendo em vista que uma elevação do preço dos imóveis, acarretada por uma onda de crédito farto e pela perspectiva de contínua valorização dos ativos, se reflete na aceleração e crescimento das atividades de construção civil, impactando o salário e a renda do setor. É a partir deste momento, portanto, que é possível realizar algumas mediações históricas entre as estruturas de um mercado realmente existente e as formas abstratas assumidas pelo capital ao longo de seu movimento.

Assim como na análise da terceira dimensão em sua forma mais abstrata, o mercado de crédito imobiliário assume inicialmente sua forma mais básica: a do capital portador de juros (D - D'). A relação inicial entre tomador e emprestador é uma relação tradicional de crédito, por mais que o dinheiro não seja usado como capital. A natureza do $\Delta \mathrm{D}$ advindo da reiteração do circuito D - D'é o juro, estabelecido na interação entre ofertantes e demandantes de capital.

Apesar de ser, em geral, um crédito de baixo valor, o prazo ampliado e o volume elevado de concessões fazem com que o crédito imobiliário seja tratado pelo sistema bancário como uma espécie de crédito de capital, necessitando de um funding próprio. Ou seja, tirante os casos de créditos curtos, o banco não é capaz de comportar em seu balanço um descasamento de prazo elevado, o que o impossibilita de utilizar seu fundo rotativo de crédito para financiar a modalidade crédito imobiliário. Em geral, a fonte de funding dos bancos para financiar créditos longos são ativos de longo prazo como poupanças (no caso de empréstimos tradicionais), ou a propriedade dada como garantia (no caso de hipotecas). Mas mesmo tendo como garantia o imóvel, o fato de o risco permanecer no balanço da instituição creditícia faz com que ela tome muitos cuidados para conceder créditos longos, limitando o escopo daqueles que podem ter acesso a essa modalidade de crédito.

No caso americano, a forma encontrada para evitar os problemas decorrentes do descasamento de prazos e ampliar a oferta de crédito imobiliário foi a securitização do crédito por meio da criação das agências governamentais. A Fannie Mae e a Freddie Mac (assim como posteriormente a Ginnie Mae, já na década de 1970) foram agências criadas com o intuito de securitizar os créditos imobiliários emitidos por bancos e financiadoras, diluindo os riscos associados ao crédito e, assim, liberando capital destas instituições para novas rodadas de 
concessão. Inicialmente, a securitização mantinha o "padrão" do capital portador de juros, apenas transferindo o risco de inadimplência para as agências governamentais, que por sua vez receberiam prêmios e a garantia do imóvel no caso de default. A lógica ainda era típica do crédito, onde o tomador paga juros ao emprestador, que agora repassa parte desse montante para as agências públicas que securitizam o empréstimo.

Este padrão de securitização, conhecido como "originate-to-hold", foi mantido até meados da década de 1970, a partir do momento em que, dadas mudanças regulatórias nos mercados financeiro e creditício, as agências públicas e os bancos privados passaram a revender os créditos securitizados, criando-se um mercado secundário de negociação de títulos de dívida ${ }^{17}$. A formação destes mercados ocasiona uma transformação na natureza do mercado de crédito e dívida: se antes se carregava as dívidas até a maturidade, mantendo-se a forma de capital portador de juros, agora se transforma em títulos a relação de dívida criada no momento da concessão do crédito, em uma dinâmica que ficou conhecida como "originate-todistribute". Neste momento, forma-se no mercado de crédito imobiliário o que aqui já se denominou capital fictício, ou seja, um título de dívida transacionável que espelha uma relação de crédito e débito já consumada. O crédito torna-se uma espécie de commodity livremente transacionada, alterando-se inclusive as regras de sua concessão ${ }^{18}$ para atender à crescente demanda do mercado secundário por novas hipotecas.

A partir do momento em que os títulos de dívida se tornam ativos financeiros negociados nos mercados secundários, uma série de agentes passa a participar deste mercado visando diferentes objetivos, suplantando a lógica dos agentes que atuavam sob a égide do "originate-to-hold". Agora, o objetivo maior não é a obtenção de lucro $(\Delta \mathrm{D})$ na forma juros decorrente dos empréstimos concedidos, mas a valorização dos estoques de riqueza fictícia representados pelos títulos de dívidas negociados nos mercados secundários. A dinâmica da concessão de crédito ao mutuário, principal fonte da demanda por novas hipotecas até então, acaba se subordinado à lógica mais geral da valorização dos títulos, tornando-se acessória na criação de valor fictício. Completa-se assim uma inversão das formas, onde a oferta de crédito por parte do emprestador (lender) responde não mais à demanda por crédito advinda do mutuário, mas às pressões pela geração de novas hipotéticas oriundas dos investidores financeiros.

Neste caso, pode-se observar empiricamente como o surgimento de novas dimensões altera a articulação e as relações entre as diversas formas de capital, sem abolir as formas pretéritas. As novas formas de valorização nascem no seio das antigas, em um movimento

(17) O Acordo da Basileia, firmado em 1988, foi fundamental para o crescimento destes mercados, já que expurgar os créditos do balanço reduz a necessidade de manutenção de capital contra os riscos de crédito decorrentes da manutenção das operações de crédito no ativo bancário.

(18) Além das mudanças das Fixed Rate Mortgages (FRM) para as Adjustable Rate Mortgages (ARM), o próprio processo de análise do histórico de crédito dos clientes passa por profundas alterações, não mais se fundamentando nas condições reais de pagamento e nas garantias apresentadas pelos clientes, mas sim em seu histórico de crédito, sem maiores considerações acerca de sua atual situação. Desta forma, podem-se comparar históricos de crédito de diferentes clientes e classificá-los mais facilmente em diversas categorias, facilitando o processo de negociação do título de dívida posteriormente e realizando uma verdadeira comoditização das relações de crédito. 
constante de adequação das formas (de valorização) em relação ao conceito (de capital), rearranjando as relações hierárquicas previamente estabelecidas. A ascensão dos mercados secundários de negociação de títulos de dívida securitizados e do capital fictício, ao invés de abolir a forma "capital portador de juros" que prevalecia sob a lógica do "originate-to-hold", estabelece uma relação sincrética e de interdependência com esta, relegando-a a uma função subordinada na cadeia de valorização, entretanto, sem prescindir dela. Esta relação está exposta tanto em depoimentos prestados por agentes participantes do mercado financeiro ${ }^{19}$ quanto pelo crescente volume de securitização e dos mercados de negociação destes títulos.

O crescimento do mercado secundário de Private Label Securities (PLS) evidencia a relevância que o capital fictício assumiu na dinâmica do mercado de crédito imobiliário. Esta centralidade é confirmada pelos depoimentos dos participantes destes mercados, ao afirmarem que a demanda por novas hipotecas, ao invés de ser dada pelo ritmo de crescimento da demanda dos tomadores de empréstimos, era ditada pelo apetite dos investidores financeiros, que viam na securitização dos títulos de dívida um negócio altamente lucrativo ${ }^{20}$. A partir desta transformação, os objetivos dos agentes financeiros mudam. Em primeiro lugar, busca-se a transferência dos riscos, por meio do processo de securitização que tira as operações de crédito dos balanços dos bancos e das entidades que concedem os créditos. Em segundo lugar, objetivase a valorização dos títulos da dívida securitizada, que pode ocorrer tanto por uma queda nas taxas de juros, quanto pela melhora na classificação de risco do ativo negociado. O capital portador de juros torna-se uma função e forma subsidiária dos ativos, abrindo espaço para a lógica do capital fictício, que passa a comandar o processo de criação e valorização dos ativos.

O deslocamento da principal fonte de demanda por novas hipotecas rumo aos mercados secundários só é possível quando tais mercados estão "completos". O mercado pode ser considerado completo quando todas as condições para a livre e constante negociação dos títulos está dada, possibilitando aos agentes montar e desmontar suas posições e estratégias com certa facilidade. Para isso, é preciso que os mercados secundários estejam dotados de liquidez, profundidade e volume suficientes para permitir, a qualquer investidor que queira nele atuar, a certeza de que seus investimentos não são apenas rentáveis, como também flexíveis e seguros do ponto de vista da montagem de seu portfólio. Ao descrever as características de um mercado "completo", Jarrow (2011) afirma:

(19) Ao comentar a crescente demanda do mercado financeiro por hipotecas subprime, Levetin e Wacther (2012) citam interessante depoimento de um agente que atuava no mercado financeiro à época dos acontecimentos: "Apesar do excesso de oferta de crédito hipotecário, o mercado de financiamento habitacional não pôde produzir um volume suficiente de notas para as PLS [Private Label Securities] e, assim, para os cash-CDOs - CDOs cujos bens eram PLS e outros valores mobiliários. Como Gillian Tett observou, durante 2005 e 2006, 'o grande segredo sujo do mundo da securitização foi que havia um apetite tão frenético por mais e mais empréstimos subprime para reempacotar em CDOs que o fornecimento de empréstimos tinha começado a ficar para trás"” (Levetin; Watcher, 2012, p. 1245, grifo GSM, tradução livre).

(20) Vários exemplos de depoimentos neste sentido encontram-se no relatório final do FCIC. Para fins de ilustração, destaca-se o trecho de um depoimento do presidente da CountryWide, uma das maiores empresas originadoras de hipotecas dos EUA nos anos 2000, onde ele admite que a geração de novas hipotecas era completamente destinada aos mercados secundários: "O presidente da Countrywide e COO David Sambol disse à Comissão que, enquanto um empréstimo não afetasse a empresa do ponto de vista financeiro ou reputacional, a Countrywide era 'um vendedor de títulos para Wall Street'. A estratégia de negócios essenciais da Countrywide era 'originar o que era vendável no mercado secundário'. A empresa vendeu ou securitizou $87 \%$ dos US\$ 1,5 trilhão em hipotecas originadas entre 2002 e 2005” (FCIC, 2011:105, tradução livre). 
Um mercado completo é um mercado no qual qualquer padrão de fluxo de caixa desejado por um investidor em uma data futura pode ser obtido pela negociação de valores mobiliários disponíveis, talvez de forma dinâmica ao longo do tempo. Por exemplo, suponha que um investidor quer um fluxo de caixa de US\$ 1,00 em exatamente um ano, se a taxa de juros de um título de 3 meses do Tesouro é entre 50 e 100 pontos de base naquela época. Em um mercado completo, o investidor pode construir uma carteira de securities negociadas, talvez mudando sua composição ao longo do tempo, o que geraria esse fluxo de caixa desejado. O mercado de dívida, portanto, é completo se qualquer fluxo de caixa relacionado a estas obrigações, em qualquer data futura, possam ser construídas por uma estratégia de negociação dinâmica de emissão de dívida subjacente (Jarrow, 2011, p. 9, tradução livre).

Os Collateral Debt Obligations (CDOs) ${ }^{21}$ tiveram importante papel na consolidação da forma capital fictício nos mercados de crédito imobiliário, apesar de se mostrarem insuficientes para completar o mercado $^{22}$. Ele pode ser compreendido como uma forma transitória entre a lógica da terceira e da quarta dimensão, já que ao mesmo tempo em que é utilizado para re-securitizar ativos (como no caso do asset CDO), também é um instrumento utilizado para "agrupar e empacotar" derivativos, já na lógica da quarta dimensão (como no caso do synthetic CDO $)^{23}$. Pode-se argumentar, além do mais, que mesmo o asset $\mathrm{CDO}$ pode ser entendido como uma espécie "primitiva" de derivativo, já que seu preço depende da ocorrência de um evento (alterações na classificação das PLS que lhe servem de garantia). Seu valor, portanto, se altera em função da variação de preço de um ativo de referência, assim como os contratos de derivativos. Por outro lado, o asset CDO ainda possui vínculos (mesmo que difusos) com a propriedade de um título de dívida, além de ter sua remuneração principal advinda do pagamento dos juros das hipotecas securitizadas, e não das variações no valor dos ativos de referência, o que o afasta da forma derivativo pura ${ }^{24}$.

A criação dos CDOs só pode ser pensada dentro da lógica da violação da lei da troca de equivalentes. Os custos para criação de um CDO não se justificariam caso os ativos usados

(21) Collateralized Debt Obligations (CDO) são produtos estruturados complexos, que compram exposição a um conjunto de títulos de dívida (em geral RMBS, dívidas de cartões de crédito, de veículos, de crédito estudantil etc.) de diversas origens para reordená-los em novas tranches, gerando um novo produto financeiro no processo de securitização. Neste novo produto, as tranches superiores (com débitos de melhor qualidade) são as últimas a serem afetadas no caso de inadimplência no conjunto de créditos securitizados no CDO.

(22) Tal insuficiência está relacionada ao fato de que as tranches mais arriscadas dos CDOs só se tornaram "viáveis" com a entrada em cena dos investidores comprados (short), que assumiam estratégias comprado-vendido (short-long) e utilizavam as tranches equity dos CDOs para realizá-las. Antes disso, o mercado secundário de CDO era praticamente inexistente.

(23) Estes produtos consistem basicamente em um agrupamento de CDS que, assim como os asset CDOs, são divididos em tranches de acordo com a qualidade do ativo (CDS) subjacente. São CDOs que possuem CDS como conteúdo.

(24) Esta compreensão de que o CDO não é propriamente um derivativo, apesar de possuir algumas semelhanças, está em concordância com a legislação contábil dos EUA, conforme descreve Levetin e Watcher (2012): "É importante notar que esta mudança afetou somente CDOs sintéticos, porque os cash CDOs nunca foram sujeitos a um regime de contabilidade de derivativos (...), apesar de serem derivativos no sentido de que o seu valor se deriva do desempenho de um conjunto de ativos subjacentes. O tratamento de derivativos sob a regulamentação SFAS 133 requer, nomeadamente, que um instrumento deva exigir 'nenhum investimento líquido inicial ou um investimento líquido inicial menor do que seria exigido para outros tipos de contratos, o que se esperaria possuir uma resposta semelhante às mudanças nos fatores de mercado.'[...] Cash - CDOS exigem um investimento inicial líquido para comprar ativos do CDO. CDOs sintéticos, particularmente os que possuem uma superior-senior piece, corresponderiam a esta definição" (Levetin; Watcher, 2012, p. 1240, nota 221, grifo GSM, tradução livre). 
como garantia não aumentassem de preço quando da venda final do CDO. Ou seja, as PLS que compõem o CDO só serão re-securitizadas caso possam ser vendidas por um valor maior do que seriam se não fossem reorganizadas em um $\mathrm{CDO}^{25}$, fazendo com que o mesmo título passe a ter um valor maior após ser incorporado a um CDO. Além do ganho com os juros e com a valorização fictícia, o que se vê neste caso é o ganho mercantil puro, decorrente da violação da lei da troca de equivalentes.

De acordo com Jarrow (2011, p. 16), os CDOs não ajudam a completar o mercado, tendo em vista que os ativos que lhe servem de garantia são negociáveis por si só. Por outro lado, o autor não reconhece o evidente fato de que, ao reorganizar os ativos e criar hierarquias de remuneração, os CDOs "criam" mercado para ativos que antes eram completamente ilíquidos, como por exemplo as tranches compostas com hipotecas subprime. Mais que isso, estes instrumentos financeiros atraem investidores pelo simples fato de ordenarem os ativos em uma gradação de qualidade, possibilitando a adoção de diferentes estratégias no que se refere à exposição ao risco.

O Credit Default Swap (CDS) ${ }^{26}$, por sua vez, contribuiu para completar o mercado, dotando-lhe de mecanismos de transferência de riscos e ampliação da liquidez. Ao atrair investidores short (comprados), os CDS ampliam a liquidez do mercado e possibilitam de maneira direta a cobertura de riscos inerentes as diferentes posições assumidas pelos investidores ${ }^{27}$.

\section{A quarta dimensão, o mercado de crédito imobiliário e sua crise}

O mercado de crédito imobiliário adentra o que aqui denominamos de quarta dimensão a partir do momento em que os derivativos de crédito passam a ditar a dinâmica da demanda e da precificação de novas hipotecas. As características da quarta dimensão se fazem presentes nestes mercados: a separação entre a posse e a rentabilidade do ativo (como é o caso do naked CDS), o ganho de aposta $\left(\Delta D^{*}\right)$ derivado da variação de preço de ativos sem obrigatoriamente a necessidade de investimento prévio (dado que o mercado de CDS é basicamente um mercado

(25) “A imperfeição do mercado que permitiu ao $\mathrm{CDO}$ e $\mathrm{CDO}^{2}$ existir foi uma violação da regra de não arbitragem. Análoga à criação de um ABS (Asset Backed Securitie), os custos de criação de um CDO são bastante grandes, incluindo advogado, avaliação e taxas de investimento bancário (...). Os ativos de um CDO teriam um valor negativo e os CDOs não poderiam ser criados, a menos que os títulos ABS no conjunto de garantias estivessem subvalorizados e/ou os títulos CDO emitidos fossem sobrevalorizados" (Jarrow, 2011, p. 15, tradução livre).

(26) O CDS consiste em um derivativo de crédito, um contrato que estabelece um "seguro" de crédito para o lender no caso de alterações na classificação de risco, renegociação dos ativos subjacentes ou inadimplência do borrower, ou seja, um contrato que só se consuma com a ocorrência de um evento específico.

(27) "Em princípio, os credit default swaps deveriam ter deixado os mercados financeiros mais eficientes e melhorar a alocação de capital. Historicamente, os investidores que financiaram as empresas por meio de dívida, tinham de assumir o risco de crédito destas empresas. Agora, os investidores que fornecem o capital não precisam ser quem assume o risco de crédito. Em vez disso, o risco de crédito pode residir com os investidores que estão melhor equipados para suportá-lo. Separar o custo do financiamento e o risco de crédito também introduz uma maior transparência no preço do crédito. Tomados em conjunto, estes benefícios do credit default swaps devem reduzir o custo de capital para empresas” (Stulz, 2010, p. 75, grifo GSM, tradução livre). 
de balcão, as margens exigidas eram muito reduzidas ou inexistentes) e a proeminência na formação dos preços (via arbitragem) dada a liquidez e profundidade destes mercados.

Três são as formas pelas quais os derivativos modificam as características institucionais do mercado imobiliário, atribuindo-lhe uma nova dinâmica. Em primeiro lugar, os derivativos (juntamente ao conjunto de inovações financeiras) passam a ter papel central na precificação do crédito imobiliário e, portanto, na demanda por novos imóveis. Em segundo lugar, o caráter elástico dos derivativos possibilita uma maior liquidez e alavancagem ao mercado, ampliando seus horizontes e dando maior elasticidade ao ciclo de crédito. Por fim, a transfiguração do mercado de crédito imobiliário atinge o conjunto do mercado financeiro ao interconectar o balanço financeiro de seus agentes, mesmo que de uma forma que não apareça em seus balanços oficiais (operações off-balance).

O mercado de CDS cresce exponencialmente ao longo dos anos 2000, em particular a partir de 2003, influindo direta e indiretamente na formação de preços dos imóveis. Em primeiro lugar, concorre para a manutenção de taxas de juros baixas no mercado imobiliário, dada a existência de arbitragem entre o mercado de CDS e o mercado de títulos securitizados, o que influenciou a taxa cobrada ao tomador final. Em segundo lugar, permite a transferência de riscos entre agentes, levando-os a elevar o volume de crédito ofertado e permitir o acesso a empréstimos para pessoas com histórico de crédito questionável ou inexistente, dada a possibilidade de se proteger (hedge) ou repassar o risco da operação para outros agentes ${ }^{28}$.

Com a expansão dos naked $\operatorname{CDSs}^{29}$, cresce o volume do mercado de derivativos de crédito, incluem-se novos agentes no processo e, desta forma, eleva-se a influência dos derivativos sobre o preço das hipotecas e dos imóveis. A posição assumida pelo comprador do naked CDS pode ser considerada a mais compatível com o derivativo em sua forma mais pura e abstrata, pois prescinde de qualquer relação de propriedade sobre um ativo. Exatamente por este fato, possibilita uma alavancagem elevada e permite aos agentes se posicionarem e levarem à frente suas estratégias de investimento, incorrendo em baixíssimos custos de capital. Ao mesmo tempo, o naked CDS também serve de conteúdo para a criação do synthetic CDO, complexificando e obscurecendo ainda mais as relações patrimoniais entre os agentes. A

(28) A função de servir como hedge de operações de crédito cresceu entre os bancos que negociam CDS, conforme afirmam Ashcraft e Santos (2007): “(...) Há evidências de que os bancos estão usando cada vez mais este mercado para cobrir os riscos de crédito que têm origem por meio de seus negócios de empréstimo. De acordo com uma pesquisa realizada pela British Bankers Association (2006), metade da proteção que os bancos compraram no mercado de CDS em 2005 e 2006 foi para cobrir os riscos decorrentes da sua atividade de empréstimos" (Ashcraft; Santos, 2007, p. 4). Na nota 12, prosseguem: "A evidência revelada por Minton, Stulz e Williamson (2006), mostrando que a probabilidade de um banco ser um comprador de proteção líquido está positivamente relacionada com a percentagem de empréstimos comerciais e industriais na sua carteira de empréstimos, também sugere que os bancos utilizam este mercado para gerenciar os riscos de crédito que eles constroem por meio de sua atividade de empréstimos".

(29) Naked CDS é a posição assumida por um agente que compra o seguro de um ativo que não possui, assumindo uma posição comprada em relação a um ativo sem necessitar para isso desembolsar nenhum centavo de imediato para sua aquisição. Por este motivo, diz-se que o comprador de um naked CDS assume uma posição sinteticamente comprada (synthetic short position) enquanto o vendedor assume uma posição vendida (long). 
criação do synthetic CDO faz com que agentes que antes apenas criavam CDOs e compravam CDS, se tornem eles mesmos emissores de CDS, assumindo a ponta longa (vendida) do derivativo e elevando a oferta destes contratos no mercado, reduzindo seus spreads ${ }^{30}$.

A redução dos spreads nos CDS faz com que haja uma queda, via arbitragem, nos spreads cobrados no mercado de crédito, alimentando a bolha imobiliária ${ }^{31}$. Este processo de transmissão de preços dos mercados futuros e de derivativos para os mercados à vista se confirma no caso dos CDS. A literatura conhecida como price discovery encontra no mercado de CDS a origem da precificação dos ativos, tanto no mercado de títulos (bond markets), conforme discutido em Blanco, Brennan e Marsh (2005), quanto no mercado de crédito, conforme apresentado em Norden e Wagner (2008). Para o mercado de crédito imobiliário em particular, Levetin e Wachter (2012) abordam a mesma questão quando afirmam:

(...) CDOs sintéticos comprimiram os spreads das PLS, o que por sua vez baixou as taxas de juros de hipoteca. Os spreads do CDS (o preço da proteção de CDS) estão ligados aos spreads das PLS (o rendimento da PLS) por meio de arbitragem. Quando se reduzem os spreads do CDS, fica mais barato adquirir seguros contra as PLS, o que aumenta a demanda por PLS, assim empurrando para baixo o rendimento sobre as PLS, o que reduz o custo dos empréstimos. Por outro lado, se os spreads dos CDS aumentam, é mais atraente para os investidores vendidos entrarem em CDOs sintéticos do que em PLS (ou cash-CDOs). O resultado é que, para competir, PLS e cash-CDOs tem de aumentar seus rendimentos, o que se traduz em um aumento nas taxas de juros de hipoteca. Spreads crescentes teriam tornado mais caro para o investidor comprado realizar sua posição de CDS e teria também restringido a oferta de crédito hipotecário, esmagando, assim, a bolha imobiliária que os investidores comprados queriam ver construída até colapsar. Usar os CDOs sintéticos como o veículo para "encurtar" o mercado imobiliário escondeu a visão negativa dos investidores comprados, permitindo a eles fazer mais negócios com prêmios de risco menores (Levetin; Wachter, 2012, p. 1246, grifo GSM, tradução livre).

Do outro lado da operação, encontram-se investidores que compram os synthetic CDOs e assumem a ponta comprada da operação. Estes investidores (em sua maioria hedge funds) foram fundamentais para viabilizar a criação de novos CDOs, pois tinham uma estratégia comprada-vendida em que a parte vendida ficava por conta das equity tranches dos CDOs e a parte comprada era realizada mediante a aquisição de derivativos de crédito contidos em synthetic CDOs. Ao adquirirem as equity tranches dos CDOs, os hedge funds viabilizam a negociação do restante das tranches do $\mathrm{CDO}$ (mezzanine e AAA-rated tranches), as quais são relativamente fáceis de vender, mas precisam de algum agente que assuma o risco pelas equity

(30) "Considerando que havia um número limitado de instituições que venderiam diretamente a proteção de CDS em uma PLS - principalmente a AIG e as seguradoras monoline — CDOs sintéticos efetivamente transformaram uma gama muito mais ampla de investidores institucionais - todos os investidores de CDO - em vendedores de proteção de CDS, desse modo abaixando os spreads dos CDS" (Levetin; Wachter, 2012, p. 1246, tradução livre).

(31) Para maiores informações sobre como ocorre a transmissão via arbitragem de um preço estabelecido no mercado de derivativos para um preço à vista, ver a seção 3 de Carneiro; Rossi; Mello e Chiliatto-Leite (2015). 
tranches para se completarem ${ }^{32}$. Desta forma, cada dólar investido em uma equity tranche ajuda a viabilizar operações completas de CDOs, incluindo as de classificação AAA e mezzanine, tendo assim um efeito muito superior ao seu investimento. Yves Smith (2010) calcula que cada US\$ 1,00 investido em CDO equity criava US\$ 533,00 de demanda por hipotecas subprime. Este movimento cria uma enorme pressão pela geração de novas hipotecas para serem securitizadas e incorporadas às tranches seniores dos CDOs, reduzindo os spreads cobrados nestes empréstimos e, em última instância, enfraquecendo as exigências para a subscrição das hipotecas ${ }^{33}$.

A precificação das hipotecas pelo mercado de CDS e a maior liquidez e profundidade destes mercados são apenas duas faces da forma tomada pelo mercado de crédito quando adentra a quarta dimensão. Outra questão crucial diz respeito à maior interconexão e alavancagem observada entre os participantes destes mercados, que ajuda a explicar a velocidade e gravidade que tomou a crise. Com o espraiamento destes novos instrumentos financeiros pelo mercado de crédito, a interpenetração patrimonial ${ }^{34}$ dos agentes cresce, já que todos os agentes se encontram alavancados em transações financeiras realizadas entre si. Os agentes podem se encontrar equilibrados do ponto de vista de sua estratégia comprado-vendido e, ao mesmo tempo, guardarem uma enorme trilha de relações de crédito e débito entre si. Imagine-se o seguinte exemplo, representado na Figura 1:

1) O banco A compra PLSs e, utilizando-as como garantia, cria um CDO e o vende para o banco B. Nesta primeira operação, o banco B fica comprado no ativo de referência, enquanto o banco A assume uma posição neutra.

2) Para evitar a exposição assumida no ativo e neutralizar (hedge) sua posição comprada em PLS, o banco B compra um CDS do banco A, já que a compra de proteção significa ficar vendido no ativo em questão. Agora, o banco A fica comprado em referência ao CDO e o banco B fica com sua posição neutralizada.

3) Por sua vez, o banco A vai ao mercado e encontra o banco C disposto a assumir a posição comprada ao vender-lhe um naked CDS (já que é um CDS sobre um CDO que está

(32) "CDOs sintéticos tornaram mais barato para o pequeno investidor comprar proteção de CDS para as PLS (e CDOs) e permitiu uma estratégia vendido-comprado de comprar as frações júnior a fim de obter o fluxo de caixa para financiar a proteção de CDS sobre as parcelas "mezanino" (e, no caso de CDOs, ter controle sobre quais ativos entraram e compõem o CDO). CDOs sintéticos, assim, aumentaram a demanda dos investidores "comprados" por frações subordinadas de PLS nos CDOs, que, a curto prazo, elevaram a oferta de capital no mercado de hipotecas" (Levetin; Watcher, 2012, p. 1249, grifo GSM, tradução livre).

(33) "A maior oferta de CDOs baixou o rendimento que CDOs tinham de oferecer para serem vendidos, que por sua vez significou menor pressão sobre o rendimento dos ativos de PLS subjacente dos CDOs, que por sua vez, manteve baixo o custo das hipotecas" (Levetin; Watcher, 2012, p. 1248, grifo GSM, tradução livre).

(34) Curiosamente, a maior parte das operações de derivativos mantem-se fora do balanço das instituições financeiras, não constituindo assim parte de seu patrimônio efetivo. Por outro lado, todas estas interconexões off-balance vêm à tona no momento da deflagração da crise e da necessidade de se liquidar os contratos de derivativos, contabilizando enormes prejuízos para os agentes envolvidos que ficaram expostas e especularam na direção errada. Desta forma, apesar de os derivativos não representarem ipsis literis uma "interconexão patrimonial" entre os agentes, não deixam de sê-lo de forma potencial. 
em posse do banco B). Desta maneira, o banco A neutraliza sua posição comprada, enquanto o banco $\mathrm{C}$ fica vendido.

4) $\mathrm{O}$ banco $\mathrm{B}$, de posse do $\mathrm{CDO}$, destrincha-o e, juntamente a outros débitos que possui, cria dois novos $\mathrm{CDO}^{2}$, vendendo-os para o banco $\mathrm{C}$ e para o banco $\mathrm{D}$. Ambos os bancos que compram os $\mathrm{CDO}^{2}$ ficam comprados no ativo, enquanto o banco B se desfaz de sua posição comprada, mantendo apenas a posição vendida do CDS adquirido na transação 2.

5) O Banco C, estando duplamente exposto no ativo (tanto através do $\mathrm{CDO}^{2}$ adquirido na operação 4 quanto do naked CDS negociado na operação 3), compensa sua posição comprada ao negociar com o Banco D um synthetic CDO. O banco D, ao vender este produto, fica comprado, reforçando sua posição já assumida quando da aquisição do $\mathrm{CDO}^{2}$ na operação 4.

6) Nesta última operação, temos o banco B vendido devido ao CDS adquirido na operação 2 e o banco D comprado. Para neutralizarem suas posições, o banco B vende o CDS que possui ao banco $\mathrm{D}$, completando a neutralização da posição dos bancos.

Figura 1

Fato estilizado ilustrando interpenetração patrimonial entre agentes financeiros

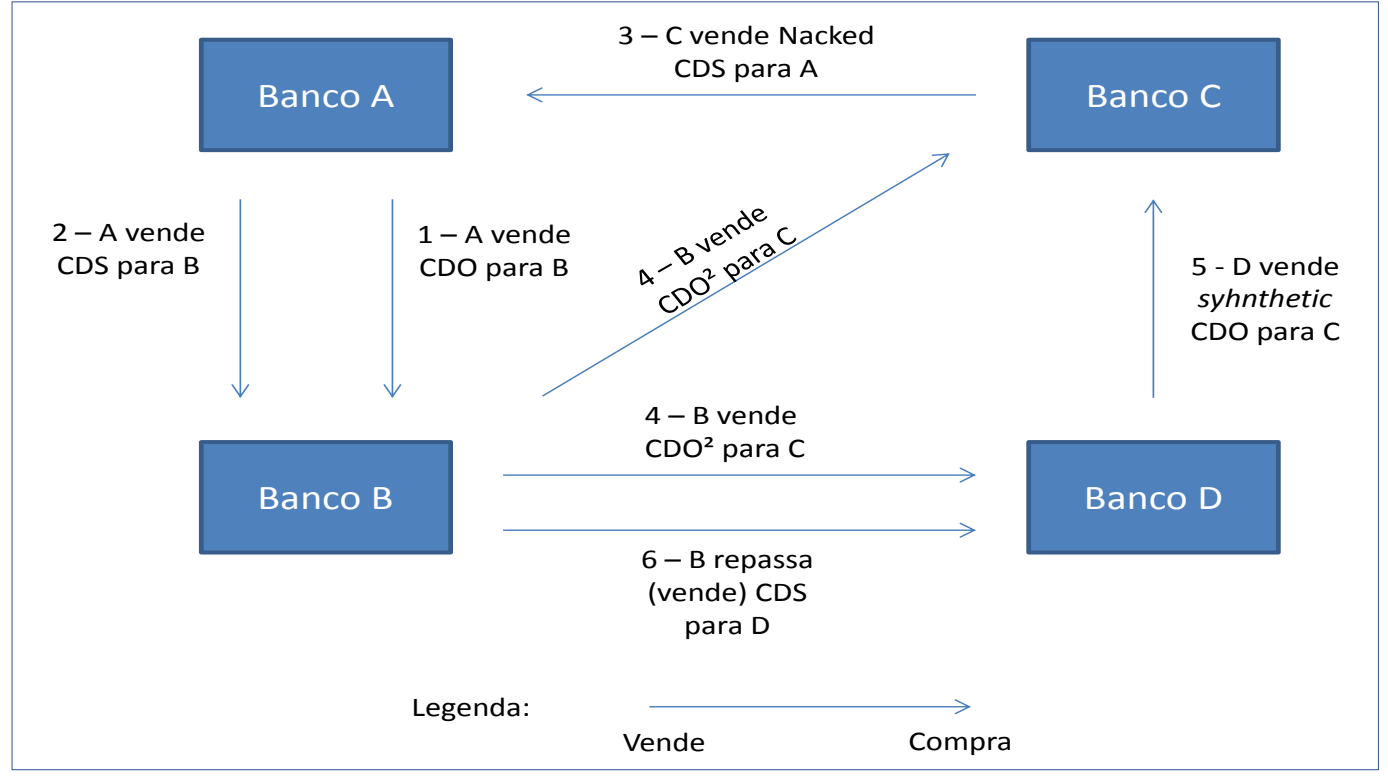

Fonte: Elaboração própria.

Ao final deste exemplo hipotético, todos os agentes encontram-se equilibrados do ponto de vista de sua estratégia vendido-comprado e, ao mesmo tempo, guardam uma enorme trilha de relações de crédito e débito entre si. A ruptura de algum destes elos da cadeia pode se revelar desastrosa para o conjunto do sistema financeiro, como foi o clássico caso da quebra 
do banco Lehman Brothers. A questão, portanto, não é qual o tamanho "ótimo" das instituições financeiras ${ }^{35}$, mas sim as relações financeiras e patrimoniais assumidas por elas ao longo do processo de securitização e negociação dos derivativos.

A interconexão patrimonial não é exclusividade da forma derivativo, podendo ser observada já na forma capital fictício presente na terceira dimensão ${ }^{36}$. Apesar disso, esta interconexão assume características particulares quando o capitalismo chega à quarta dimensão. Em primeiro lugar, cresce a transversalidade dos mercados possibilitada pela forma derivativo, que interliga não apenas os agentes em suas posições ativas e passivas, mas também os diferentes mercados de maneira mais direta. Isso significa dizer que alterações súbitas na precificação de um mercado específico transferem-se imediatamente para outros mercados que, por diversas vezes, não guardam relações diretas com os primeiros. Isso ocorre devido ao tipo de exposição e estratégia adotadas pelos investidores em derivativos, que ao "comoditizarem" os riscos, adotam estratégias de investimento que desconsideram as particularidades reais de cada mercado. Este fato fica sumarizado nos derivativos de índices, que ao invés de apostarem na variação de preços de um ativo particular, apostam na variação de preço de um conjunto de ativos que nem sempre guardam relação um com o outro no que tange à estrutura de preços. Esta estratégia só faz sentido em mercados onde os preços estão determinados na esfera das finanças, em particular dos mercados futuros e da forma derivativos, pois a co-variação de preços nos diferentes ativos que compõem os índices só é possível pela força exercida pelos investidores financeiros em sua precificação, não pela estrutura de custos pretensamente comum que compartilham.

Em segundo lugar, aliada à transversalidade dos mercados, a forma derivativo possui como característica marcante a crescente opacidade dos instrumentos financeiros, criando dificuldades na aferição da real situação patrimonial de cada agente financeiro. Como os mercados de derivativos são em sua maioria negociados nos mercados de balcão e como estas operações não são necessariamente registradas nos balanços oficiais dos agentes financeiros (inexistindo inclusive provisão de capital na forma líquida em diversas ocasiões), a aferição da situação financeira de cada agente torna-se praticamente impossível. A combinação destes dois fatores, opacidade e transversalidade, faz com que os efeitos de uma crise setorial rapidamente tomem a forma de crise sistêmica, atingindo um conjunto grande de mercados que, a princípio, guardam poucas relações com o mercado específico em que a crise se originou. Adicionalmente, ao iniciar o processo de desalavancagem e desmonte de suas posições, os agentes financeiros encontram os mercados travados pela completa falta de informação a respeito da saúde financeira de seus participantes. Quando as inter-relações entre agentes

(35) Uma das interpretações consagradas para explicar a crise e o resgate de boa parte do sistema financeiro é a de que os bancos, por meio de um processo de concentração e centralização ocorrido no sistema financeiro ao longo das últimas décadas, se tornaram "grandes demais para falhar" (too big to fail). Apesar de reconhecer o gigantismo dos bancos e a oligopolização ocorrida no setor, o argumento aqui exposto é que este não é o fator explicativo principal no que tange à necessidade de salvar as instituições financeiras. Mais grave que seu tamanho relativo é a interpenetração patrimonial dos agentes, proporcionada pelo desenvolvimento sem paralelos dos instrumentos financeiros e da elevada alavancagem permitida para tais transações.

(36) Pode-se citar, por exemplo, a exposição que bancos assumem em suas posições ativas com ações de outros bancos. 
financeiros e diferentes mercados aumentam e ganham dimensões globais, tendo como pano de fundo um mercado desregulado e pouco transparente, o desmonte da infraestrutura da gestão da riqueza abstrata erigida e coordenada pelos grandes agentes financeiros privados torna-se mais profunda e veloz, suplantando em muito a gravidade das crises típicas observadas nos mercados da terceira dimensão.

Apesar de todos estes efeitos instabilizadores, a forma derivativo representa o sucesso do movimento do capital em sua incessante busca por formas de valorização cada vez mais abstratas. O desenvolvimento destes ativos financeiros não deve ser entendido como uma "deformação" da estrutura de mercado, mas sim como parte do movimento mais geral de concorrência e de abstração das formas de valorização do capital, que encontram na crise o seu limite momentâneo. É forçoso reconhecer que tais instrumentos financeiros criam incentivos a fraudes e fazem com que agentes elevem os riscos sistêmicos (que, por sua vez, são indevidamente classificados) com o objetivo de auferir maiores ganhos no curto prazo, mas estes procedimentos fazem parte da lógica mais geral de acumulação do capitalismo, em particular de um capitalismo onde os mercados financeiros são tão parcamente regulados. Neste cenário, os derivativos cobriram os riscos no plano microeconômico e proporcionaram um boom de crédito sem precedentes, causando grande dinamismo econômico no sistema. Por outro lado, este dinamismo se fundou em um crescente risco sistêmico na economia americana, gerado por uma bolha de crédito e de preços dos ativos, levando ao limite da alavancagem todos os agentes envolvidos no processo, até que alterações nas condições de reprodução do sistema levaram ao paroxismo o rastro de dívidas criado no período de pujança.

\section{Conclusão}

Este artigo procurou empreender uma análise dos motivos que levaram o mercado imobiliário e de crédito imobiliário dos EUA a gerar uma das maiores crises da história do capitalismo mundial. Procurou-se argumentar que, para além das falhas na supervisão observadas nas estruturas do mercado de crédito e do mercado financeiro como um todo, as transformações ocorridas nestes mercados sugerem o estabelecimento de uma nova forma de acumulação e regulação do capital, ancorada nos derivativos e aqui denominada de quarta dimensão. A quarta dimensão do capitalismo tem como característica central a proeminência dos mercados de derivativos e de sua lógica sob os mercados tradicionais de crédito. Em outras palavras, significa dizer que a dinâmica do mercado de crédito imobiliário (em particular a partir de 2005, após a maturação dos mercados de derivativo de crédito), seus preços e volume dos créditos ofertados, possuíam íntima relação com a dinâmica impressa pelo mercado de derivativos. A maior parte da demanda por novas hipotecas e as pressões baixistas sobre os spreads partiram de uma lógica relativamente "autóctone", que tinha origem nos mercados financeiros e só foi possível graças ao crescimento do mercado de CDS. Mais que isso, eram os próprios investidores vendidos de CDS que passaram a comandar a dinâmica dos mercados financeiros e, por extensão, do mercado imobiliário. 
Argumenta-se também que esta nova forma de capitalismo aumenta a interconexão patrimonial entre os diversos agentes financeiros, além de criar um cenário de elevada alavancagem de todos os investidores. Neste quadro, a quebra de um banco, mesmo que de porte médio, pode impactar profundamente as estruturas do mercado ao criar uma onda de insegurança e travar os circuitos de crédito interbancário.

Conclui-se do acima exposto que a crise financeira deflagrada em 2007/2008 só pode ter sua origem compreendida dentro de um cenário de transformação estrutural do mercado de crédito. A crise é resultado do sucesso de um modelo específico de capitalismo desenvolvido durante a última década, que possibilitou grande acumulação de riqueza durante um curto período, mas levou ao extremo o descolamento entre riqueza real e riqueza fictícia. A reversão do mercado imobiliário a partir de 2006 é apenas a causa aparente da crise que se desencadeou em 2007 e se agravou em 2008 com a quebra do Lehman Brothers. É um processo clássico em que o "ajuste" entre a riqueza financeira e a valorização "real" deve ocorrer por meio da desalavancagem dos agentes e da desinflação dos ativos financeiros, fato já amplamente discutido por Minsky (2008) ou mesmo por Fisher (1933) antes dele. Os limites deste modelo de capitalismo (assim como de todos os outros conhecidos até então) estão, portanto, inscritos dentro da lógica mais geral da produção de valor numa economia capitalista, onde o processo de valorização do capital é contraditório e limitado pelo próprio capital.

\section{Bibliografia}

AGLIETTA, M. The future of capitalism. In: CORIAT, Petit; SCHMÉDER (Ed.). The hardship of nations: exploring the paths of modern capitalism. Cheltenham: Edward Elgar, 2006. p. 9-35.

AGLIETTA, M.; REBÉRIOUX, A. Corporate governance adrift: a critique of shareholder value. Cheltenham: Edward Elgar, 2005.

ASHCRAFT, Adam B.; SANTOS, João A. C. Has the CDS market lowered the cost of corporate debt? Disponível em SSRN: http://ssrn.com/abstract=995728 or http://dx.doi.org/10.2139/ssrn.9957282009.

ASHCRAFT, Adam B.; SCHUERMANN, Til. Understanding the securitization of subprime mortgage credit. 2007. Disponível em: http://www.ny.frb.org/research/conference/2007/liquidity/Ashcraft-Schuermann_subprime_ 04Dec2007.pdf.

BELLUZZO, L. G. de Mello. Dinheiro e as transfigurações da riqueza. In: TAVARES, M.; FIORI, J. L. (Org.). Poder e dinheiro: uma economia política da globalização. Petrópolis: Editora Vozes, 1997. p. 151-194.

BLACKBURN, R. Finance and the fourth dimension. New Left Review, v. 39, p. 39-70, 2006. 
BLANCO, R.; BRENNAN, S.; MARSH, I. W. An empirical analysis of the dynamic relationship between investment grade bonds and credit default swaps. Journal of Finance, v. 60, p. 2255-2281, 2005.

BRUNNERMEIER M.K. et al. The fundamental principles of financial regulation. Geneva Report on the World Economy, Nov. 2009. Geneva: International Center for Monetary and Banking Studies, 2009.

BRYAN, D.; RAFFERTY, M. Capitalism with derivatives: a political economy of financial derivatives, capital and class. Chippenham: Palgrave Macmillan, 2006.

CARNEIRO, R.; ROSSI, P.; MELLO, G. S.; CHILIATTO-LEITE, M. The fourth dimension: derivatives and financial dominance. The Review of Radical Political Economics, v. 47, p. 641$662,2015$.

CARNEIRO, R. Globalização e integração periférica. Campinas: IE/Unicamp, 2007. (Texto para Discussão, n. 126).

CARNEIRO, R.; CHILIATTO-LEITE, M. V.; MELLO, G. S.; ROSSI, P. L. The fourth dimension: derivatives in a capitalism with financial dominance. In: POLITICAL economy and the outlook for capitalism. Joint conference AHE, IIPPE, FAPE, 2012, Paris: Political economy and the outlook for capitalism. Joint conference AHE, IIPPE, FAPE, 2012.

CHESNAIS, F. A globalização e o curso do capitalismo de fim-de-século. Economia e Sociedade, Campinas, n. 5, p. 1-30, 1995.

CHESNAIS, F. A mundialização do capital. São Paulo: Xamã, 1996.

CHESNAIS, F. A 'nova economia': uma conjuntura própria à potência econômica estadunidense. In: CHESNAIS; DUMÉNIL; LÉVY; WALLERSTEIN. Uma nova fase do capitalismo? São Paulo: Xamã, 2003. p. 43-70.

CHESNAIS, F. O capital portador de juros: acumulação, internacionalização, efeitos econômicos e políticos. In: CHESNAIS, F. (Org.). A finança mundializada: raízes sociais e políticas, configuração, consequências. São Paulo: Boitempo, 2005.

EPSTEIN, G. Financialization, rentier interests, and Central Bank policy. Department of Economics, University of Massachusetts, 2001. Mimeografado.

FARHI, M. O futuro no presente: um estudo sobre o mercado de derivativos financeiros. Tese (Doutorado)-IE/Unicamp, Campinas, 1998.

FCIC. The Financial Crisis Inquiry Report. Final report of the national commission on the causes of the financial and economic crisis in the United States. Submitted by Pursuant to Public Law 111-21 Jan. 2011. Disponível em: http://fcic.law.stanford.edu/report2011. 
Guilherme Santos Mello

FISHER, Irving (1933). The debt-deflation theory of great depressions. Econometrica, v. 1, n. 4, p. 337-357. Also published in: Revue de l'Institut International de Statistique, 1, p. 48-65, 1934. Reprinted in: FISHER, 10, p. 337-343, 1997.

GUTTMANN, R. Uma introdução ao capitalismo dirigido pelas finanças. Novos Estudos, 82, p. 11-33, 2008.

JARROW, Robert A. The role of ABS, CDS and CDOs in the credit crisis and the economy. (Working Paper, n. 2011). Disponível em: http://www.russellsage.org/sites/all/files/RethinkingFinance/Jarrow\%20ABS\%20CDS\%20CDO\%202.pdf.

IMF. Performance in the run-up to the financial and economic crisis: IMF Surveillance in 2004-07, Jan. 10, 2011.

LEVETIN, Adam J.; WACHTER, Suzan M. Explaining the housing bubble. Georgetown Law Journal, v. 100, n. 4, p. 1177-1258, 2012.

LIPUMA, E.; LEE, B. Financial derivatives and the rise of circulation. Economy and Society, v. 4, n. 3, p. 404-427, 2005.

MARX, K. The capital. London: GBR. The Electric Book Company Ltd., 2001. v. I, II, III. http://site.ebrary.com.

MARX, K. O capital: crítica da economia política. São Paulo: Civilização Brasileira, 2006. V. I.

McKENZIE, R. A. Casino capitalism with derivatives: fragility and instability in contemporary finance. Review of Radical Political Economics, v. 43, n. 2, p. 198-215, 2011.

MELLO, G. S. Os derivativos e a crise do subprime: o capitalismo contemporâneo em sua quarta dimensão. Tese (Doutoramento)-IE/Unicamp, Campinas, 2013.

MINSKY, H. P. (1986). Stabilizing an unstable economy. New York: McGrawHill, 2008.

NORDEN L.; WAGNER, W. (2007). Credit derivatives and loan pricing. Journal of Banking \& Finance, 2008.

PALLEY, T. Financialization: what it is and why it matters. Levy Economics Institute, 2007. (Working Paper, n. 525).

PLIHON, D. As grandes empresas fragilizadas pelas finanças. In: CHESNAIS, F. (Org.). A finança mundializada. São Paulo: Boitempo Editorial, 2005.

ROTTA, T. N. Dinheiro inconversível, derivativos financeiros e capital fictício: a moderna lógica das formas. Dissertação (Mestrado)-Universidade de São Paulo, São Paulo, 2008.

SCHACKLE, G. L. S. Time and thought. The British Journal for the Philosophy of Science, v. 9, n. 36, p. 285-298, Feb. 1959.

STRANGE, S. Casino capitalism. Oxford: B. Blackwell, 1986. 
STULZ, René M. Financial derivatives: Lessons from subprime crises. Journal of Economic Perspectives, v. 24, n. 1, p. 73-92, Winter 2010.

TAVARES, M. C. A retomada da hegemonia norte-americana. In: TAVARES, Maria da Conceição; FIORI, José Luís (Org.). Poder e dinheiro: uma economia política da globalização. Petrópolis: Editora Vozes, p. 27-53. Esse artigo foi publicado também na Revista de Economia Política, Vol. 5, No. 2, abril/junho, 1985. São Paulo: Ed. Brasiliense, 1997.

TERADA, T. Recent trends in Japanese foreign-exchange margin trading. Bank of Japan Review, Sept. 2008.

VAN DER ZWAN, N. Making sense of financialization. Socio-Economic Review, 12, 2014. 